\title{
Low-Cost Hydrogen Distributed Production System Development
}

Final Technical Report

November 2009

\author{
Prepared by \\ C.E. (Sandy) Thomas, Ph.D., President \\ Franklin D. Lomax, Ph.D, CTO \& Principal Investigator, and \\ Maxim Lyubovski, Ph.D. \\ $\mathrm{H}_{2} \mathrm{Gen}$ Innovations, Inc. \\ Alexandria, Virginia 22304 \\ with \\ Cost-sharing partner: \\ Süd Chemie, Inc.
}

Under the U.S. Department of Energy Cost-shared contract \# DE-FG36-05G015026

Rick Farmer, DOE HQ Technology Manager and Paul Bakke, DOE Field Project Officer 


\section{Executive Summary}

$\mathrm{H}_{2} \mathrm{Gen}$, with the support of the Department of Energy, successfully designed, built and field-tested two steam methane reformers with $578 \mathrm{~kg} /$ day capacity, which has now become a standard commercial product serving customers in the specialty metals and PV manufacturing businesses. We demonstrated that this reformer/PSA system, when combined with compression, storage and dispensing (CSD) equipment ${ }^{1}$ could produce hydrogen that is already cost-competitive with gasoline per mile driven in a conventional (non-hybrid) vehicle. We further showed that mass producing this $578 \mathrm{~kg} /$ day system in quantities of just 100 units would reduce hydrogen cost per mile approximately $13 \%$ below the cost of untaxed gasoline per mile used in a hybrid electric vehicle. If mass produced in quantities of 500 units, hydrogen cost per mile in a FCEV would be $20 \%$ below the cost of untaxed gasoline in an HEV in the 2015-2020 time period using EIA fuel cost projections for natural gas and untaxed gasoline, and $45 \%$ below the cost of untaxed gasoline in a conventional car. This $20 \%$ to $45 \%$ reduction in fuel cost per mile would accrue even though hydrogen from this $578 \mathrm{~kg} /$ day system would cost approximately $\$ 4.14 / \mathrm{kg}$, well above the DOE hydrogen cost targets of $\$ 2.50 / \mathrm{kg}$ by 2010 and $\$ 2.00 / \mathrm{kg}$ by 2015 .

We also estimated the cost of a larger, $1,500 \mathrm{~kg} /$ day SMR/PSA fueling system based on engineering cost scaling factors derived from the two $\mathrm{H}_{2} \mathrm{Gen}$ products, a commercial $115 \mathrm{~kg} /$ day system and the $578 \mathrm{~kg} /$ day system developed under this DOE contract. This proposed system could support 200 to 250 cars per day, similar to a medium gasoline station. We estimate that the cost per mile from this larger $1,500 \mathrm{~kg} / \mathrm{day}$ hydrogen fueling system would be $26 \%$ to $40 \%$ below the cost per mile of untaxed gasoline in an HEV and ICV respectively, even without any mass production cost reductions. In quantities of 500 units, we are projecting per mile cost reductions between $45 \%$ (vs. HEVs) and 62\% (vs ICVs), with hydrogen costing approximately $\$ 2.87 / \mathrm{kg}$, still above the DOE's $2010 \$ 2.50 / \mathrm{kg}$ target.

We also began laboratory testing of reforming ethanol, which we showed is currently the least expensive approach to making renewable hydrogen. Extended testing of neat ethanol in micro-reactors was successful, and we also were able to reform E-85 acquired from a local fueling station for 2,700 hours, although some modifications were required to handle the $15 \%$ gasoline present in E-85. We began initial tests of a catalyst-coated wall reformer tube that showed some promise in reducing the propensity to coke with E-85. These coated-wall tests ran for 350 hours. Additional resources would be required to commercialize an ethanol reformer operating on E-85, but there is no market for such a product at this time, so this ethanol reformer project was mothballed pending future government or industry support.

\footnotetext{
${ }^{1}$ Achieving these hydrogen costs estimates also requires a reduction in the cost of compression, storage and dispensing (CSD) equipment which is beyond the scope of this project. For total hydrogen cost estimation purposes, we assumed that the CSD equipment cost targets were achieved, using the DOE financial and feedstock parameters specified in the 2007 DOE hydrogen production technical plan (http://www1.eere.energy.gov/hydrogenandfuelcells/mypp/pdfs/production.pdf )
} 


\subsection{Introduction}

\subsection{Project Goals}

The two main objectives of this project were:

- to design, build and test a steam methane reformer and pressure swing adsorption system that, if scaled up and mass produced, could potentially meet the DOE 2015 cost and efficiency targets for on-site distributed hydrogen generation, and

- to demonstrate the efficacy of a low-cost renewable hydrogen generation system based on reforming ethanol to hydrogen at the fueling station.

\subsection{Hydrogen Cost Background}

Most hydrogen is made at large central production plants for use in various industrial processes by reforming natural gas and water. While the production cost of this industrial grade merchant hydrogen is relatively low, the costs of either liquefying or compressing this hydrogen for transport by truck to a distributed fueling infrastructure are too high to be competitive with gasoline in an HEV. For example, the DOE's H2A cost estimation model ${ }^{2}$ projects that hydrogen made at a future (2025) central plant would still cost $\$ 6.37 / \mathrm{kg}$ if delivered by liquid tanker truck and $\$ 4.15 / \mathrm{kg}$ even if delivered by pipeline in the LA area ${ }^{3}$, well above the DOE $\$ 2 / \mathrm{kg}$ to $\$ 3 / \mathrm{kg}$ goal, as shown in Table 1. The H2A case studies show that the on-site SMR plus compression, storage and dispensing (CSD) is the least costly option at $\$ 3.50 / \mathrm{kg}$ using the $\mathrm{H} 2 \mathrm{~A}$ case study input data $^{4}$. The next lowest option is central SMR with pipeline delivery at $\$ 4.15 / \mathrm{kg}$, but this will not be an option for most parts of the country ${ }^{5}$ for many years until increased hydrogen demand in a given region justifies the expense of building pipelines.

\footnotetext{
${ }^{2}$ Total costs including production, delivery and CSD as summarized in case studies on the H2A web page: http://www.hydrogen.energy.gov/h2a prod studies.html

${ }^{3}$ This estimate from a central SMR plant delivered by pipeline assumes $20 \%$ fuel cell electric vehicle market penetration in the LA basin.

${ }^{4}$ We are projecting an "all-in" cost of approximately $\$ 2.87 / \mathrm{kg}$ in mass production based on the technology developed under this contract; see section below.

${ }^{5}$ One exception is in Los Angeles, where an existing hydrogen pipeline could be used to supply near-by fueling stations.
} 
Table 1. Estimated hydrogen costs $(\$ / \mathrm{kg})$ for various production and delivery modes, based on the DOE H2A model case studies

\begin{tabular}{|l|r|l|r|r||r|}
\hline \multicolumn{1}{|c|}{$(\$ / \mathrm{kg})$} & Production & $\begin{array}{c}\text { Delivery } \\
\text { Mode }\end{array}$ & $\begin{array}{c}\text { Delivery } \\
\text { Cost }\end{array}$ & \multicolumn{1}{c||}{ CSD } & $\begin{array}{r}\text { Total } \\
\text { Cost }\end{array}$ \\
\hline Distributed Generation & & & & & \\
\hline SMR & 1.61 & & - & 1.88 & 3.49 \\
\hline Electrolyzer & 4.23 & & - & 1.82 & 6.05 \\
\hline Central Production & & & & & \\
\hline Natural Gas SMR & 1.44 & Tube Trailer & 3.49 & 1.88 & 6.81 \\
\hline (add \$0.20/kg for CCS) & 1.44 Liquid & 3.05 & 1.88 & 6.37 \\
\hline & 1.44 & Pipeline & 0.83 & 1.88 & 4.15 \\
\hline Coal Gasification & 1.69 & Tube Trailer & 3.49 & 1.88 & 7.06 \\
\hline (add \$0.34/kg for CCS) & 1.69 & Liquid & 3.05 & 1.88 & 6.62 \\
\hline & 1.69 & Pipeline & 0.83 & 1.88 & 4.40 \\
\hline Biomass Gasification & 1.61 & Tube Trailer & 3.49 & 1.88 & 6.98 \\
\hline & 1.61 & Liquid & 3.05 & 1.88 & 6.54 \\
\hline & 1.61 & Pipeline & 0.83 & 1.88 & 4.32 \\
\hline Central Electrolysis & 4.50 Tube Trailer & 3.49 & 1.88 & 9.87 \\
\hline (5.5 cents/kWh) & 4.50 Liquid & 3.05 & 1.88 & 9.43 \\
\hline & 4.50 Pipeline & 0.83 & 1.88 & 7.21 \\
\hline Advanced Nuclear & 2.93 Tube Trailer & 3.49 & 1.88 & 8.3 \\
\hline (2025 time period) & 2.93 Liquid & 3.05 & 1.88 & 7.86 \\
\hline & 2.93 & Pipeline & 0.83 & 1.88 & 5.64 \\
\hline
\end{tabular}

\section{3 $\mathrm{H}_{2}$ Gen Background}

$\mathrm{H}_{2}$ Gen Innovations, Inc. was formed in 2001 exclusively to develop small-scale steam methane reformers to produce hydrogen for industrial and hydrogen energy applications. The founding members of $\mathrm{H}_{2} \mathrm{Gen}$, in conjunction with three industrial gas companies, ${ }^{6}$ had extensively analyzed various methods of producing and delivering hydrogen for fuel cell electric vehicles (FCEV) as the lead contractor to the Ford Motor Company under their cost-shared contract with the DOE. In the course of that multimillion dollar, multi-year program starting in 1994, we concluded that making hydrogen at the fueling station is the least costly option ${ }^{7}$, as later confirmed by the DOE's H2A models described above. On-site production from water and natural gas eliminates the cost of transporting hydrogen from a central facility. It essentially utilizes the existing natural gas and water pipeline systems as the backbone of the distributed hydrogen infrastructure. Some analysts had dismissed hydrogen as an energy carrier citing the enormous cost of installing a national hydrogen pipeline system; with distributed hydrogen production, no pipelines would be required for many years or decades.

The HGM-2,000, SMR/PSA system under development by $\mathrm{H}_{2}$ Gen at the start of this contract in 2004/2005, had a capcity of $115 \mathrm{~kg} /$ day. This would be enough hydrogen to

\footnotetext{
${ }^{6}$ Air Products, BOC and Praxair

${ }^{7}$ C.E. Thomas, B.D. James, I.F. Kuhn, F.D. Lomax, and G.N. Baum, "Direct hydrogen-fueled proton exchange membrane fuel cell system for transportation applications: hydrogen infrastructure report," prepared by Directed Technologies, Inc for the Ford Motor Company under DOE Contract No. DE-AC0294CE50389, July 1997.
} 
fill approximately 20 cars per day ${ }^{8}$, far less than a typical gasoline station that can refuel 250 to 300 cars per day. The DOE H2A model assumes an on-site reformer with a capacity of $1,500 \mathrm{~kg} /$ day which could support 250 cars/day, assuming an average capacity factor of $70 \%$. This capacity is appropriate for a mature hydrogen fueling system, but it is 13 times larger than the HGM-2000.

Several companies have built a few medium-sized SMRs in this $1,500 \mathrm{~kg} / \mathrm{day}$ size range, but they are considered small in the main SMR industrial gas business. In addition, these large commercial SMRs are typically one-of-a-kind, site-built engineering projects with separate reactors, separate heat exchangers, and separate PSA gas cleanup systems. As such, they are too expensive and too large to be sited at a fueling station.

The $\mathrm{H}_{2} \mathrm{Gen}$ approach is to mass produce small-scale integrated SMR/PSA systems at our production plant and ship them to the site, ready for use. This cuts manufacturing costs and significantly reduces on-site engineering and installation costs. Our units are typically hooked up to natural gas, water and electricity and are ready to operate within several days to a week, compared to many months for on-site construction.

Scaling up from our standard $115 \mathrm{~kg} /$ day system to $1,500 \mathrm{~kg} /$ day in one step did not seem appropriate for $\mathrm{H}_{2} \mathrm{Gen}$ for two reasons: a 13-times scaling was too large a jump from an engineering perspective, and it will be many years before there will be a viable market in the hydrogen fueling business for this larger unit. We therefore decided to build a system with five times larger output, $10,000 \mathrm{scfh}$ or $578 \mathrm{~kg} / \mathrm{day}$ as an intermediate step that would allow us to determine the cost scaling relationships for all the system components, and result in an SMR that has current market potential in the existing industrial gas business.

\subsection{Steam Methane Reformer Development}

Our program plan was to further optimize the HGM-2000 to assure that the HGM10,000 scale up would be as efficient and low-cost as possible. The initial development work was therefore conducted on the HGM-2000 platform prior to the design and construction of the first HGM-10,000..

\subsection{The HGM-2000 System}

The HGM-2000 is a thermally integrated, compact, SMR plus PSA in one transportable container. It was designed using the principles of DFMA ${ }^{9}$ - Design for manufacture and assembly - to minimize the cost of building and assembling the units in a factory. The $\mathrm{H}_{2}$ Gen engineers learned this methodology while working for the Ford Motor Company on their DOE cost-shared contract to develop their first direct-hydrogen fuel cell electric vehicle.

\footnotetext{
${ }^{8}$ Assuming that FCEVs have 65 miles/kg fuel economy, travel 12,000 miles per year, and refuel once every 8 days and assuming that the average capacity factor of the SMR/PSA system is $70 \%$.

${ }^{9}$ DFMA is a registered trademark of Boothroyd and Dewhurst
} 
The block diagram of the HGM unit is shown in Figure 1. The unit runs on line natural gas. A small fraction of the natural gas powers a burner, with most of the gas being pressurized to $280 \mathrm{psi}$, after which it passes through a small desulfurizer bed before being mixed with steam and entering the main reactor tubes. The reactor tubes are filled with a special precious metal catalyst developed jointly with our partner, Süd Chemie. This high activity catalyst is durable and sulfur-tolerant, permitting the use of a small desulfurizer bed and very small reactor tubes.

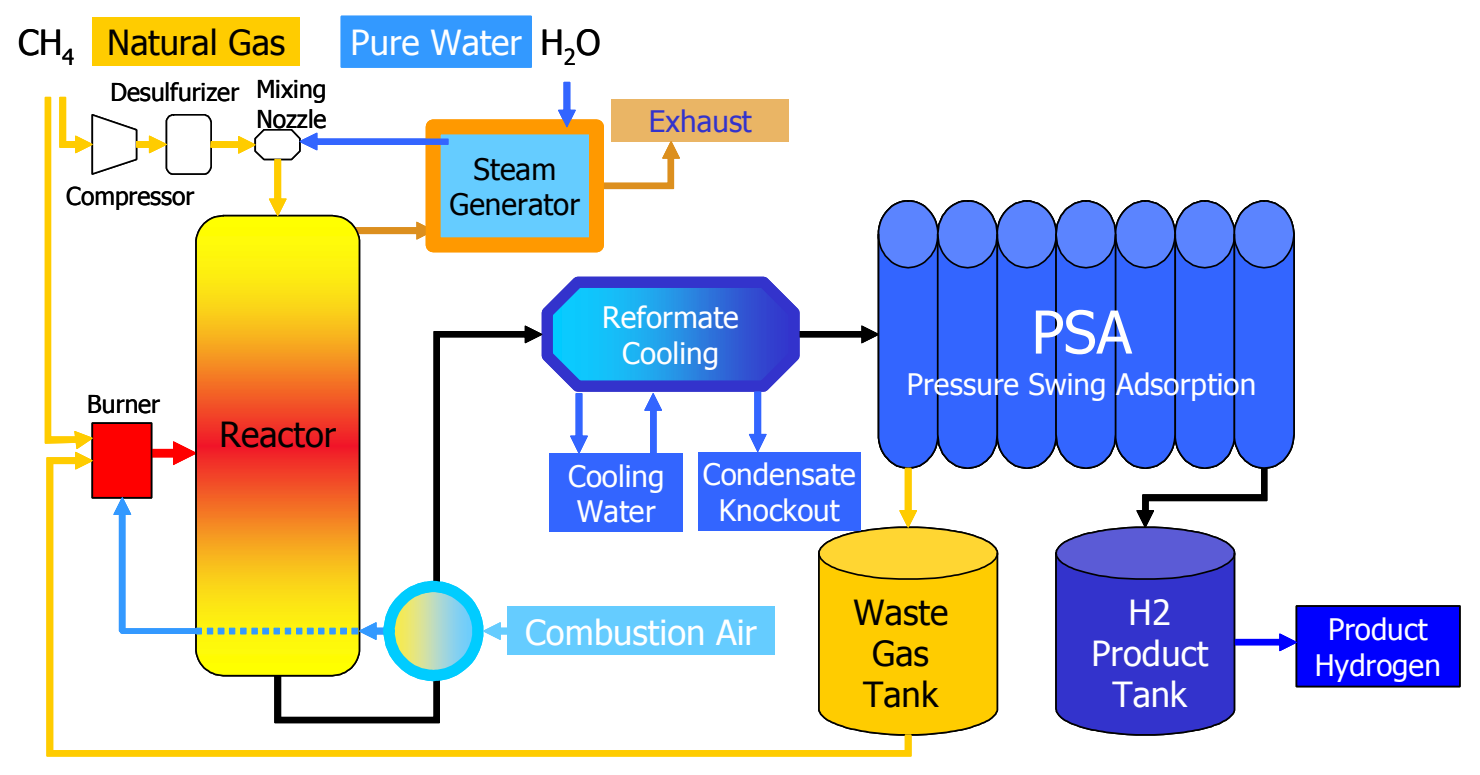
Steam Methane
Steam generation, reformate cooling, Reforming SMR heat recovery, waste gas recovery
PSA Purification and $\mathrm{H} 2$ generation

Figure 1. Flow diagram of the HGM-2000 combined steam methane reformer and pressure swing adsorption system

The natural gas/steam mixture travels down through the reactor tubes, generating hydrogen and carbon monoxide in a highly endothermic reaction at temperatures reaching $800^{\circ} \mathrm{C}$ to $900^{\circ} \mathrm{C}$ near the burner:

$$
\mathrm{CH}_{4}+\mathrm{H}_{2} \mathrm{O}=\mathrm{CO}+3 \mathrm{H}_{2}
$$

The syngas then travels through the slightly exothermic water gas shift (WGS) reaction zone, producing more hydrogen:

$$
\mathrm{CO}+\mathrm{H}_{2} \mathrm{O}=\mathrm{CO}_{2}+\mathrm{H}_{2}
$$

Outside air is used to cool the WGS zone to maximize hydrogen production. The heat extracted from the WGS zone is then fed to the burner, improving thermal efficiency.

Ideally, the net reaction is then: 


$$
\mathrm{CH}_{4}+2 \mathrm{H}_{2} \mathrm{O}=\mathrm{CO}_{2}+4 \mathrm{H}_{2} .
$$

Thus one methane molecule (and one carbon atom) produces four hydrogen molecules. Half the hydrogen comes from water, which is one of the reasons that hydrogen made from natural gas cuts greenhouse gas emissions by half or more when used in a fuel cell electric vehicle.

After cooling the reformate from the reactor, it is passed into the pressure swing adsorption (PSA) system. The valves in the PSA system are electronically controlled, such that the purity can be automatically adjusted to meet the customer's needs. Five to six nine's purity suitable for PEM fuel cells can be achieved by speeding up the PSA cycles, but for those customers that can tolerate lower purity, the hydrogen production rate and system efficiency can be increased slightly by slowing down the PSA cycles.

The tailgas from the PSA still contains small quantities of $\mathrm{CO}$, $\mathrm{H}_{2}$ and $\mathrm{CH}_{4}$ that has some heating value. This tailgas is therefore fed back to the burner, and in fact provides 80 to $85 \%$ of the heat needed to run the reactor.

Figure 2 shows an HGM-2000 operating at a customer's industrial site in Mississippi, and Figure 3 shows the first use of the HGM-2000 in a hydrogen fueling application: in this case providing hydrogen for Ford ICE shuttle buses at a Chevron station in Orlando, Florida.

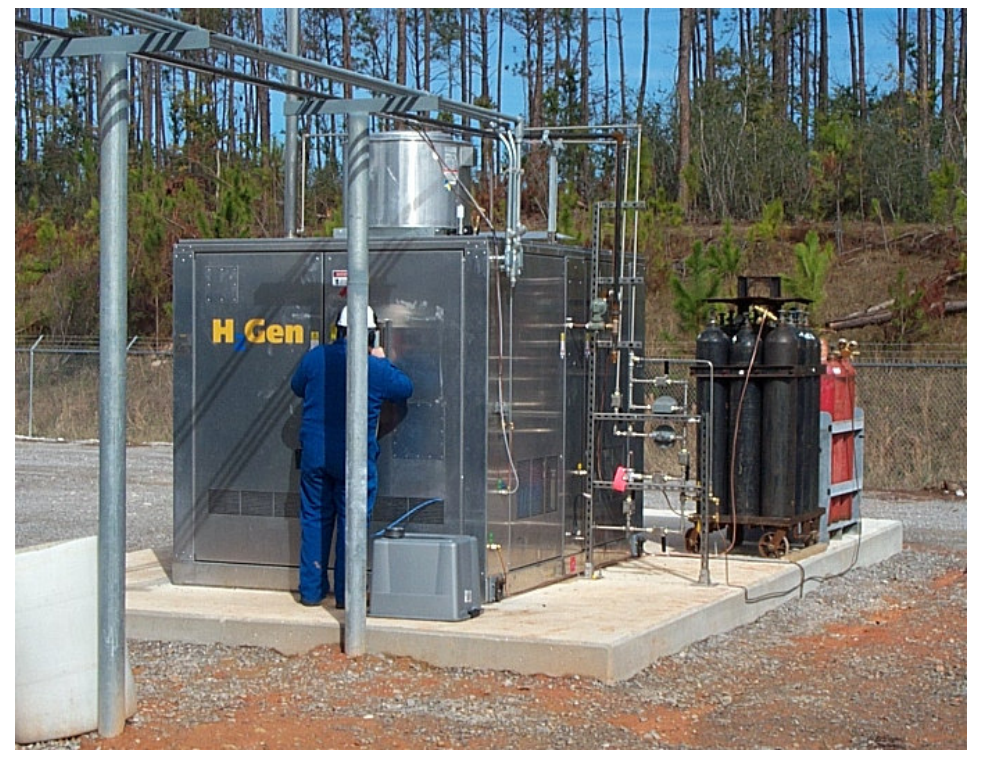

Figure 2. An HGM-2000 SMR/PSA system installed at an industrial site

\subsection{HGM-2000 Improvements}

The first tasks under this DOE contract were directed at improving the performance of the HGM-2000 prior to designing the HGM-10,000, the main focus of the project.

Task 1: we added a new heat exchanger to recover heat from the reformate stream to be used to raise the temperature of the natural gas entering the desulfurizer bed. Our goal was to capture $3 \mathrm{~kW}$ of heat, but achieved only $2.1 \mathrm{~kW}$ of heat recovery. 
Task 2: our second goal was to increase the HGM-2000 output by $30 \%$ to 2,600 scfh. We designed and installed two higher performance boiler systems, since steam production was a bottle neck in earlier designs. Outputs up to 2,480 scfh were achieved after multiple improvements in thermal integration catalyst developments.

Task 3: our third goal was to develop improved reformer and WGS catalysts in conjunction with Süd Chemie and to demonstrate 2,500

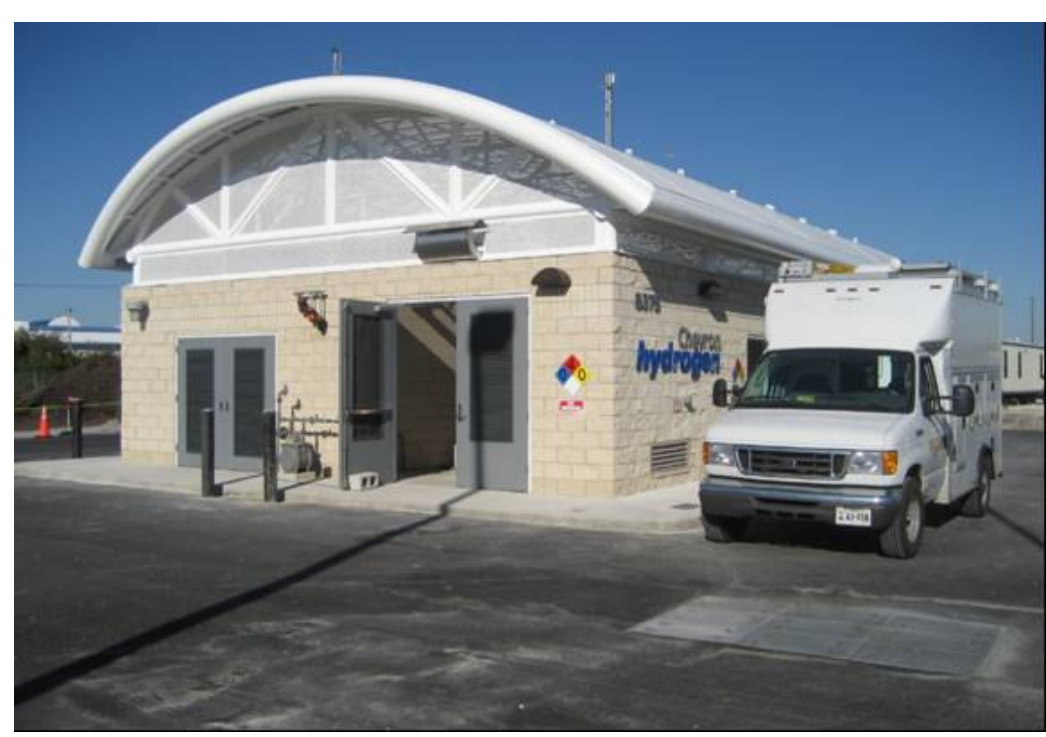

Figure 3. HGM-2000 (inside building) at the Chevron station in Orlando, Florida hours of field test time on these catalysts in a full-scale HGM-2000. The new reformer catalyst developed under the program showed no significant degradation after a cumulative 7,000 hours of pilot operation.

Süd Chemie also developed a new set of WGS catalysts that reduce methanation substantially and increased efficiency approximately 5\%. However, some of these catalysts caused the Fischer-Tropsch formation of parafins (wax), so several iterations of different processing techniques, different catalyst supports and different additives and stabilizers were required before we arrived at a stable, low-methanation, wax-free operation. To achieve these results, Süd Chemie had to revamp their test facilities to handle the high pressures corresponding to HGM operation.

Süd Chemie also had to develop an improved pre-reformer catalyst that is sulfur tolerant and carbon tolerant so that we can now reform propane and ethanol in addition to natural gas.

The results of these catalyst and thermal integration tasks are summarized in Figure 4, showing the HGM-2,000 lower heating value efficiency vs. hydrogen output. Each datum point in Figure 4 represents several hours of stable operation for different operating conditions. This is the efficiency of the SMR/PSA system excluding electricity: the LHV of hydrogen out divided by the LHV of natural gas into the system. The DOE efficiency goal includes the electrical energy in the denominator ${ }^{10}$. At rated output, we demonstrated $72 \%$ LHV natural gas efficiency; adding electrical consumption reduces this to approximately $68 \%$ total system efficiency. This is very close to the

\footnotetext{
${ }^{10}$ The DOE system efficiency calculation includes electricity energy delivered to the system in the denominator, but does not account for the upstream inefficiencies of electrical transmission and particularly electricity generation.
} 
original DOE goal of $69 \%$ system efficiency (including delivered electricity) at the time of our contract award, but the DOE has now increased that goal to $72 \%$ by 2010 and $75 \%$ by 2015 .

\section{Fuel Efficiency}

(Lower Heating Value \%)

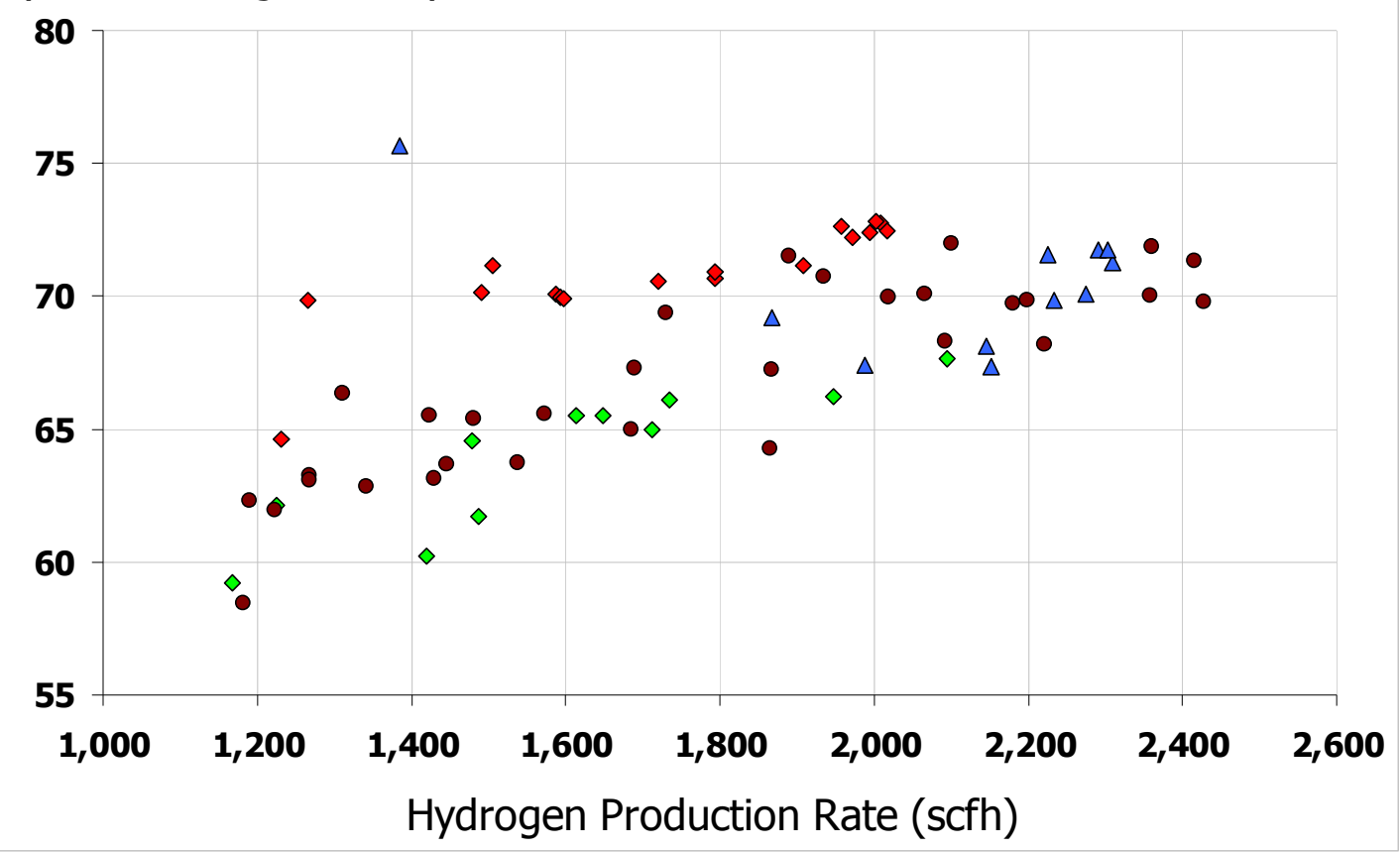

Figure 4. Measured SMR/PSA LHV efficiency (LHV H2/LHV NG) vs. hydrogen output for the improved HGM-2000

Another major catalyst development was to explore a reduction in precious metal catalyst loading. Süd Chemie prepared a series of catalysts with reduced PGM loadings that we tested in our micro-reactors. These catalysts were aged for 1,000 hours under normal HGM operating conditions, and then tested for activity. As shown in Figure 5, the precious metal loading could be reduced to $25 \%$ of the original content without adversely affecting aged activity. However, the catalyst with $12.5 \%$ of the original loading had unacceptably low activity after aging. 


\section{Activity}

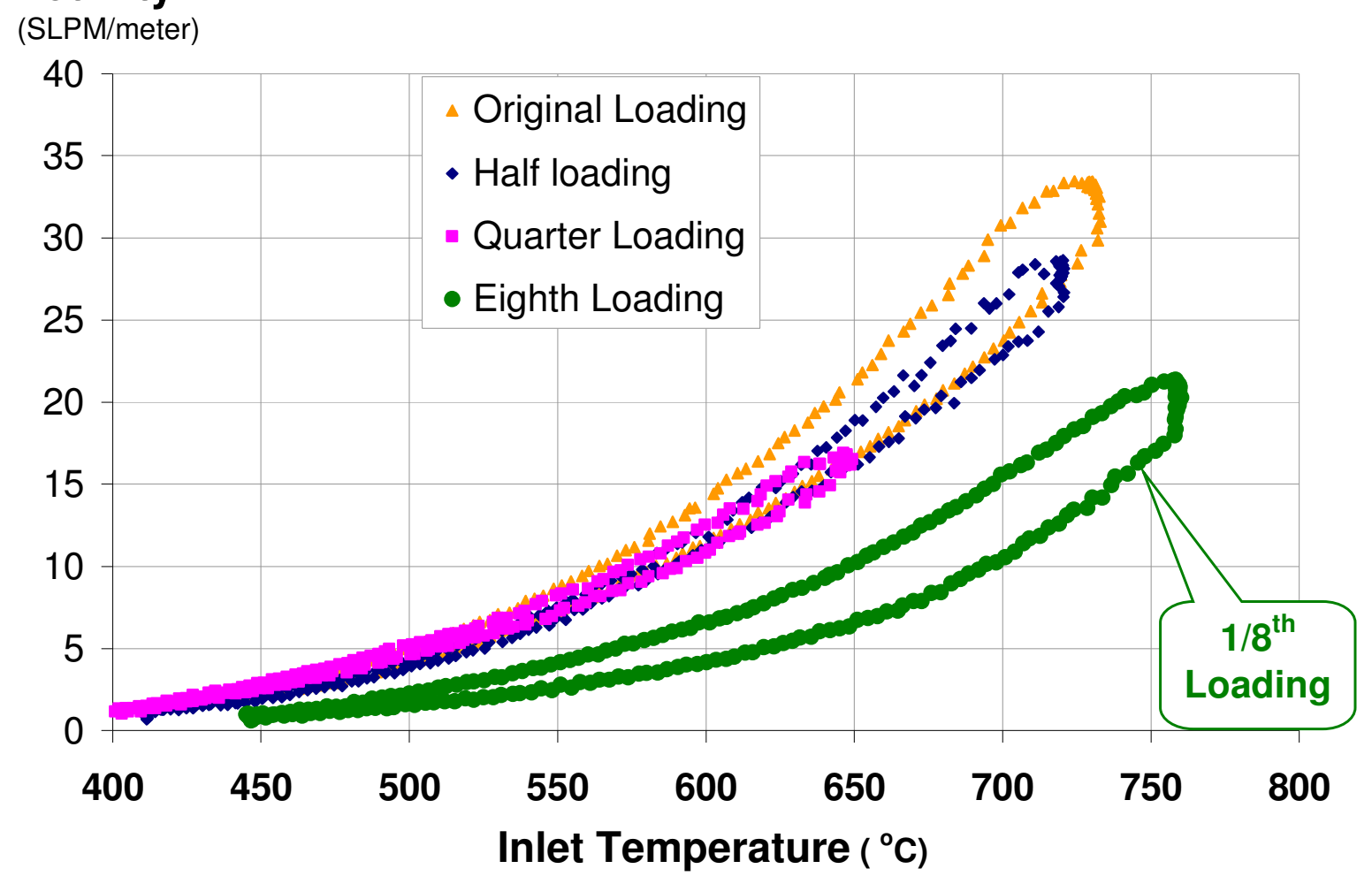

Figure 5. Measured catalyst activity after 1,000 hours run time on catalysts with $100 \%, 50 \%, 25 \%$ and $12.5 \%$ of the original HGM precious metal loading

Prior to the design of the HGM-10,000, we logged over 42,000 hours of test time with multiple HGM-2000 in the field at customers' sites, far exceeding our goal of 2,500 hours field testing. The longest-running unit by June of 2006 when the HGM-10,000 design work began had 8,500 hours of hydrogen production time. No drop in performance was detected in any of these systems.

Task 4: our fourth goal was to increase PSA recovery by $10 \%$ through improved adsorbents. During the course of this contract, we developed an extensive PSA computer simulation model and an experimental test bed to measure the characteristics of new adsorbents and a micro-PSA to calibrate measurements with simulation data (Figure 6).

Several new carbon and molecular sieve adsorbents were tested over the course of this contract. After optimization of the PSA performance utilizing these unique tools, the hydrogen recovery was improved by $11.7 \%$ compared to our target of $10 \%$. Most importantly, this simulation capability allowed us to design the HGM-10,000 PSA system efficiently while meeting our design goals on the first iteration. 

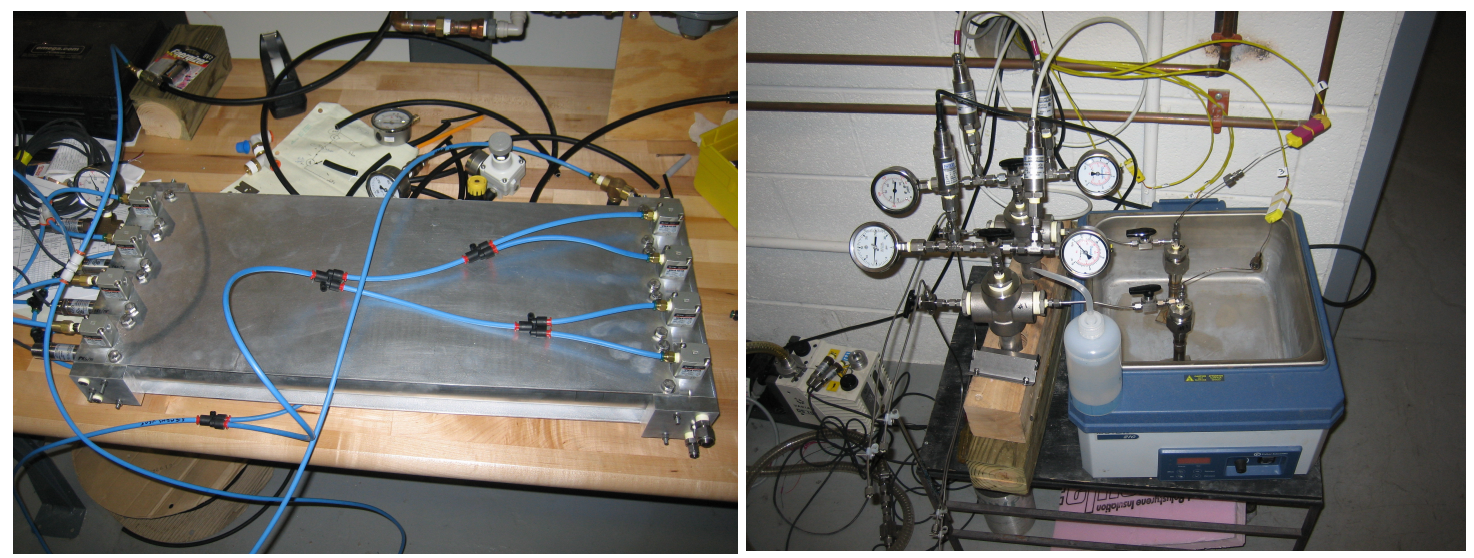

Figure 6. Micro-PSA (left) and isotherm rig (right) for PSA development at $\mathrm{H}_{2}$ Gen

\subsection{Development of the HGM-10,000}

The HGM-10,000 incorporated all of the "lessons-learned" from the HGM-2000 improvement program. One of the first tasks in developing the five-times higher capacity HGM-10,000 was to design and test a low pressure drop SMR burner. By reducing the pressure drop across the burner we were able to reduce the air blower power draw and substantially lower electricity consumption. We designed, built and tested a full-scale burner independent of the reformer itself before integrating the complete system. Figure 7 shows the results of a CFD analysis of the mixing section of the burner and the actual test firing to confirm operational parameters.
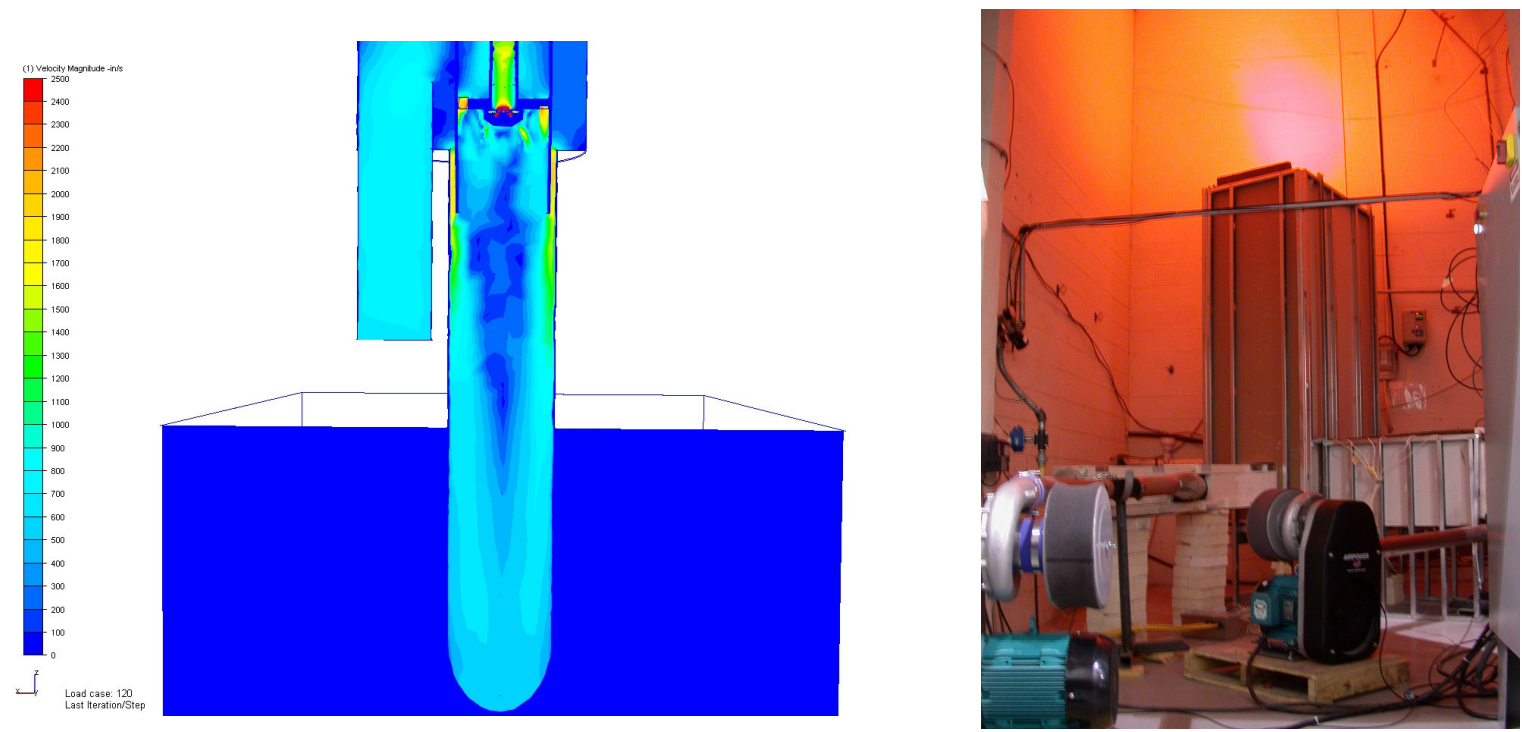

Figure 7. CFD analysis of the HGM-10,000 burner mixing area, and test firing of the burner in our facility to evaluate and optimize performance 
The HGM-10,000 SMR and PSA systems were designed to industry standards including B31-3, VIII-1, API 618, NFPA 70A, 497, 496 and CSA 5.99. A new computer system software architecture was developed for this HGM. All $\mathrm{H}_{2} \mathrm{Gen}$ systems are completely automated, including startup, shutdown and operate around the clock without any operator assistance. The initial skid built under this contract is shown in Figure 8 during construction. An 8-bed PSA system is shown on the left, the hydrogen storage tank and natural

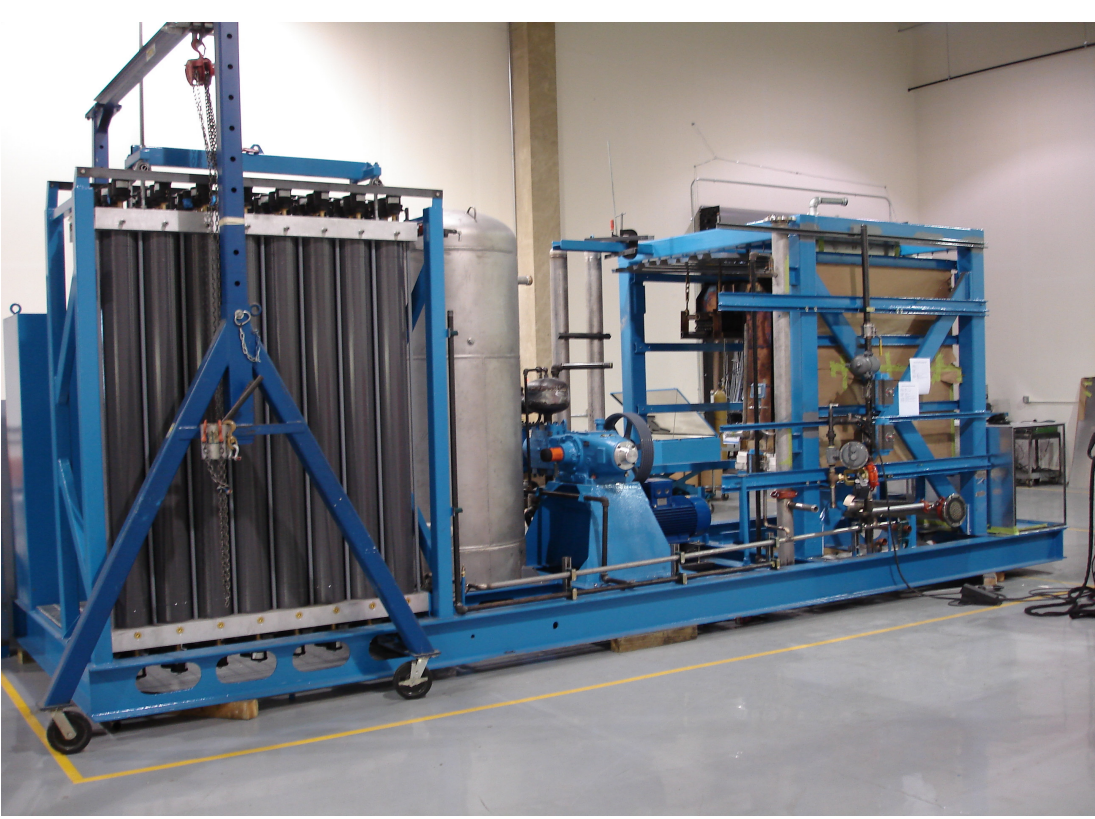

Figure 8. The first HGM-10,000 during assembly at the H2Gen plant in Alexandria, Virginia gas compressor in the center and the reformer system on the far right prior to adding plumbing and wiring.

This first HGM-10,000 was installed at a customer's site (Figure 9) in July 2007 and the hydrogen was used in the customer's plant throughout the field test period. This unit was run for 3,963 hours in the field before being shutdown and returned to the factory for detailed evaluation of the system. The maximum production rate was 8,000 scfh with a lower heating value efficiency of $70 \%$. A second $\mathrm{HGM}-10,000$ was fabricated incorporating the "lessons learned" from the first system. This second unit was installed in April 2008. To date, five more HGM-10,000's have been sold commercially for service in the metal annealing business, and also to manufacture trichlorosilane

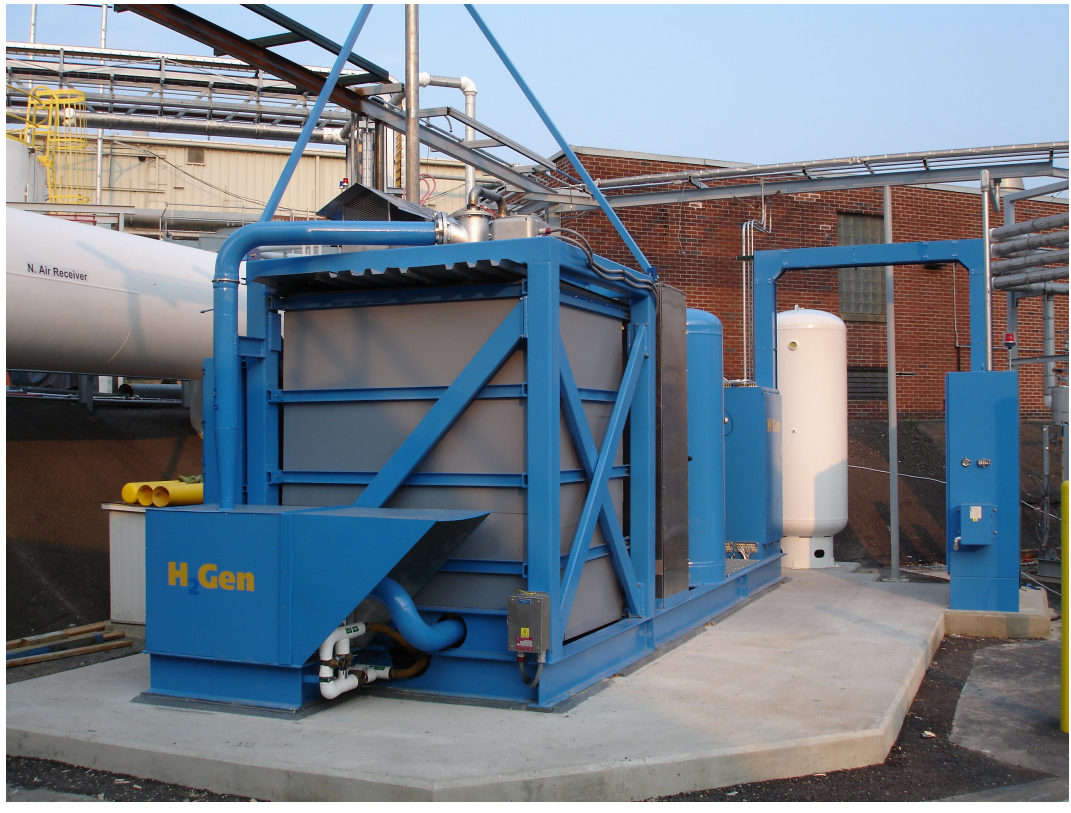

Figure 9. First HGM-10,000 installed at customer site that is used to make silicon solar cells. 


\subsection{HGM-10,000 Cost Projections $(\$ / \mathrm{kg})$}

One of the primary objectives of this contract was to validate the DOE cost targets of $\$ 2 / \mathrm{kg}$ to $\$ 3 / \mathrm{kg}$ for the delivered cost of compressed hydrogen when SMRs are mass produced in quantities of 500 . Our costing methodology was as follows, as illustrated in Figure 10:

> List known sub-assembly costs for all the components of the commercial HGM2000

$>$ List the corresponding sub-assembly costs for the HGM-10,000

$>$ Calculate scaling laws $\left[\mathrm{P}_{10 \mathrm{~K}}=\mathrm{P}_{2 \mathrm{~K}} \times(5)^{\mathrm{S}}\right]$ where " $\mathrm{S}$ " is the power law scaling factor for each sub-system.

$>$ Use these same scaling factors to estimate the sub-assembly costs for a 1,500 $\mathrm{kg} / \mathrm{day}$ system.

> Use engineering best judgment progress ratios ${ }^{11}$ for each sub-assembly to estimate the mass production costs of each component of each HGM

\section{Capital Cost Estimate Procedure (500/year manufacturing rate)}

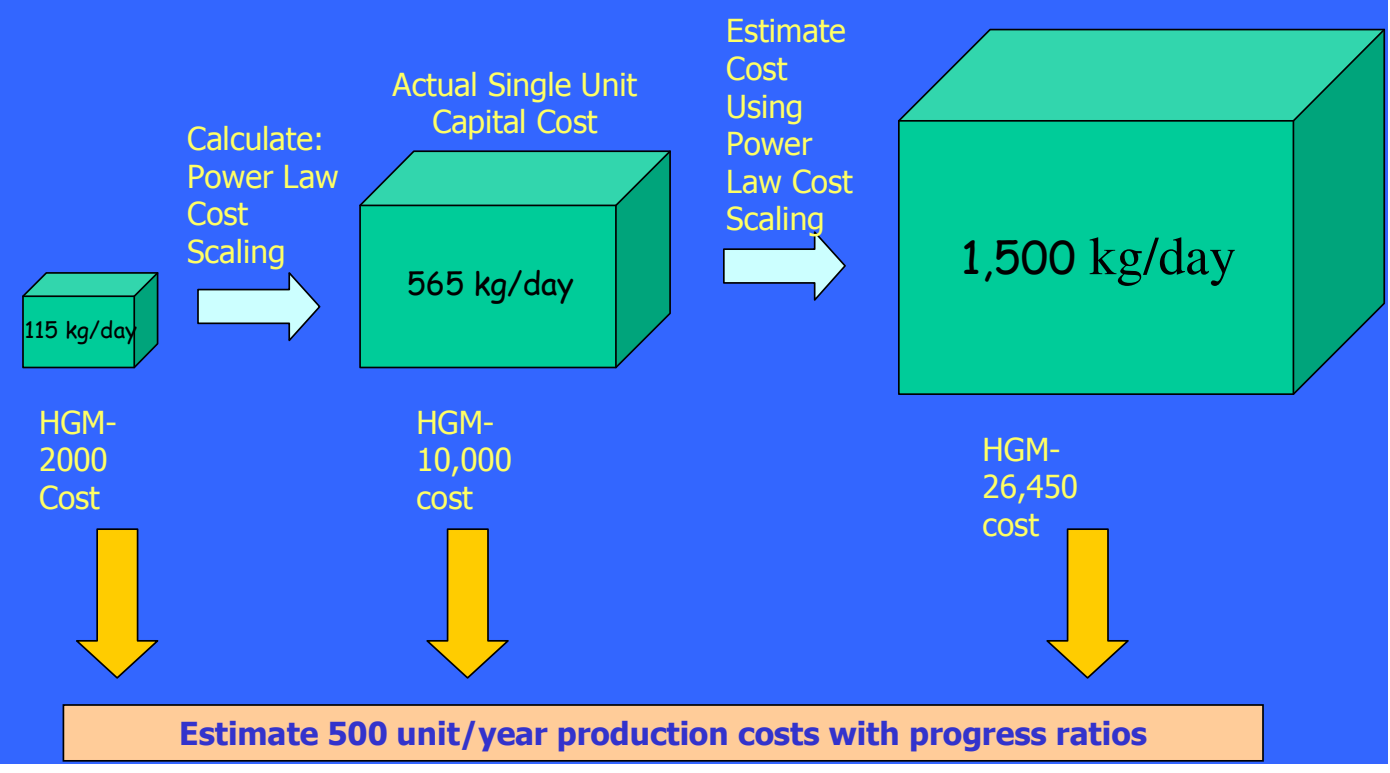

Figure 10. Costing methodology used to estimate the mass production costs of a $1,500 \mathrm{~kg} /$ day SMR/PSA/CSD fueling system in mass production of 500 units

\footnotetext{
${ }^{11}$ Some analysts use "learning curves" or "experience curves" to estimate the reduction of costs as a function of cumulative production volume. The "progress ratio" includes many factors including labor learning rates, substitution of new materials and processes, management improvements, total redesigns of the product and even new companies entering the space.
} 
The resulting power-law scaling factors and the progress ratios used in this cost assessment are summarized in Table 2 for the 12 main HGM-10,000 subsystems. Note that the cost-weighted progress ratio is only 0.95 . Numerous studies of commercial hardware have shown that the average progress ratio is roughly 0.85 . That is, the cost of most equipment drops $15 \%$ for every doubling of production. In this assessment we have assumed an average decrease in cost of only $5 \%$ for every doubling of production. Therefore this assessment is conservative regarding the likely cost reductions due to mass production.
Table 2. Calaculated capacity scale factors (from HGM-2,000 to HGM-10,000 cost data) and estimated progress ratios for major HGM components

\begin{tabular}{|c|c|c|}
\hline & $\begin{array}{l}\text { Hydrogen } \\
\text { Capacity } \\
\text { Scale Factor }\end{array}$ & $\begin{array}{c}\text { Production } \\
\text { Quantity } \\
\text { Progress } \\
\text { Ratio }\end{array}$ \\
\hline Reactor & 0.62 & 0.940 \\
\hline Catalysts & 0.70 & 0.946 \\
\hline Feed Water & 0.35 & 0.950 \\
\hline Condenser & 0.29 & 0.950 \\
\hline NG compressor & 0.25 & 0.950 \\
\hline Machine air & 0.60 & 0.950 \\
\hline Air system & 0.60 & 0.950 \\
\hline Panel \& Wiring & 0.26 & 0.950 \\
\hline PSA & 0.38 & 0.920 \\
\hline Waste Gas tank & 0.58 & 0.970 \\
\hline Product Tank & 0.10 & 0.970 \\
\hline Housing/Support Structure & 0.15 & 0.960 \\
\hline Weighted Average & 0.44 & 0.946 \\
\hline
\end{tabular}

The results of this costing process are summarized in Table 3 for the HGM-10,000 developed under this contract and for the proposed $1,500 \mathrm{~kg} /$ day system. All costs include compression, storage and dispensing to fill $35 \mathrm{MPa}$ (350 bar or 5,000 psi) tanks. Key cost parameters include:

- A $10 \%$, real, after-tax return on all capital equipment with the DOE financial parameters of $1.9 \%$ inflation, $38.9 \%$ total tax burden, 7-year MACR declining balance depreciation (the assumed equipment lifetimes are shown independently for the SMR/PSA system and the CSD system which determines the annual capital charge rate for each system, as summarized in Table 3)

- Natural gas costing at $\$ 6.85 / \mathrm{MBTU}(\mathrm{HHV})$ which is the 2015 industrial natural gas price projected in the EIA Annual Energy Outlook for 2009.

- Electricity at 8 cents $/ \mathrm{kWh}$ for both compression and SMR/PSA operation.

- The CSD system capital cost was set by the ratio of the CSD system cost to the SMR/PSA system cost in the DOE's H2A model (the CSD costs $18 \%$ more than the SMR/PSA system in the H2A model)

- The average fueling system capacity factor is $70 \%$, consistent with the DOE/H2A model. This low capacity factor accounts for the variability of hydrogen demand at a fueling station on a daily, weekly, seasonal and statistical basis.

The resulting compressed hydrogen cost projections vary from $\$ 5.63 / \mathrm{kg}$ to $\$ 4.14 / \mathrm{kg}$ for the existing HGM-10,000 to $\$ 3.83 / \mathrm{kg}$ to a predicted cost of $\$ 2.87 / \mathrm{kg}$ for the proposed $1,500 \mathrm{~kg} /$ day fueling system in production quantities of 500 units. 
Table 3. Summary of input data and resulting hydrogen cost estimates in $\$ / \mathrm{kg}$ for hydrogen fueling systems with $578 \mathrm{~kg} /$ day and $1,500 \mathrm{~kg} /$ day capacity in quantities of 1,100 and 500 each

\begin{tabular}{|c|c|c|c|c|c|c|}
\hline & \multicolumn{3}{|c|}{ HGM-10,000 } & \multicolumn{3}{|c|}{ HGM-25,950 } \\
\hline Capacity (scf/hr) & \multicolumn{3}{|c|}{10,000} & \multicolumn{3}{|c|}{25,950} \\
\hline Capacity (kg/day) & \multicolumn{3}{|c|}{578} & \multicolumn{3}{|c|}{1,500} \\
\hline Production Quantity & 1.0 & 100 & 500 & 1.0 & 100 & 500 \\
\hline HGM lifetime (years) & 15 & 15 & 15 & 15 & 15 & 20 \\
\hline HGM Annual Fixed Charge Rate & $15.5 \%$ & $15.5 \%$ & $15.5 \%$ & $15.5 \%$ & $15.5 \%$ & $13.9 \%$ \\
\hline CSM lifetime (years) & 20 & 20 & 20 & 20 & 20 & 20 \\
\hline CSM Annual Fixed Charge Rate & $13.9 \%$ & $13.9 \%$ & $13.9 \%$ & $13.9 \%$ & $13.9 \%$ & $13.9 \%$ \\
\hline Reactor Replacement (yrs) & 5 & 5 & 6 & 7 & 7 & 8 \\
\hline Final Price FOB Alexandria & $\$ 1,211,765$ & $\$ 858,466$ & $\$ 762,044$ & $\$ 1,818,426$ & $\$ 1,290,090$ & $\$ 1,145,686$ \\
\hline Total Installed HGM Costs & $\$ 1,331,544$ & $\$ 963,562$ & $\$ 862,643$ & $\$ 1,993,189$ & $\$ 1,442,675$ & $\$ 1,291,485$ \\
\hline Average Annual O\&M Cost & 60,654 & 42,530 & $\$ \quad 35,750$ & 77,411 & 55,508 & 48,049 \\
\hline \multicolumn{7}{|l|}{ Hydrogen Production Costs $(\$ / \mathrm{kg})$} \\
\hline Capital Recovery (70\% capacity factor) & 1.42 & 1.03 & 0.92 & 0.82 & 0.59 & 0.48 \\
\hline $\mathrm{O} \& \mathrm{M}$ & 0.42 & 0.29 & 0.25 & 0.21 & 0.15 & 0.13 \\
\hline Taxes \& Ins & 0.18 & 0.13 & 0.12 & 0.11 & 0.08 & 0.07 \\
\hline NG fuel @ \$6.85/MBTU & 1.18 & 1.18 & 1.18 & 1.18 & 1.18 & 1.18 \\
\hline HGM Electricity @ 8cents/kWh & $\underline{0.08}$ & $\underline{0.08}$ & $\underline{0.08}$ & $\underline{0.08}$ & $\underline{0.08}$ & $\underline{0.08}$ \\
\hline H2 Production Cost & 3.29 & 2.72 & 2.55 & 2.40 & 2.08 & 1.94 \\
\hline \multicolumn{7}{|c|}{ Estimated Compression \& Storage Costs $(\$ / \mathbf{k g})$} \\
\hline Capital Recovery & 1.50 & 1.08 & 0.97 & 0.86 & 0.63 & 0.500 \\
\hline O\&M & 0.432 & 0.313 & 0.280 & 0.249 & 0.181 & 0.162 \\
\hline Taxes \& Ins & 0.216 & 0.156 & 0.140 & 0.125 & 0.090 & 0.081 \\
\hline Compression Electricity & $\underline{0.19}$ & $\underline{0.19}$ & $\underline{0.19}$ & $\underline{0.19}$ & $\underline{0.19}$ & $\underline{0.19}$ \\
\hline Total Compression \& Storage cost & 2.34 & 1.75 & 1.58 & $\overline{1.43}$ & 1.09 & $\overline{0.94}$ \\
\hline Total Compressed H2 Cost $(\$ / \mathbf{k g})$ & 5.63 & 4.47 & 4.14 & 3.83 & 3.17 & 2.87 \\
\hline
\end{tabular}

The $\$ 2.87 / \mathrm{kg}$ hydrogen cost estimate is approximately equal to gasoline at $\$ 2.87 /$ gallon on an energy equivalent basis, since one $\mathrm{kg}$ of contains approximately the same energy as one gallon of gasoline ${ }^{12}$.

\subsection{Hydrogen Cost Projections (cents/mile)}

Drivers relate to $\$$ /gallon of gasoline today, since they know the approximate fuel economy of their gasoline vehicles. Their annual fuel costs are only dependent of the cost of gasoline in $\$ /$ gallon and their driving habits. But hydrogen used in a fuel cell electric vehicle will be much less expensive per mile traveled than gasoline used in a regular car, since the fuel economy of a FCEV is at least 2 to 3 times greater than the fuel economy of a gasoline ICV. Their annual fuel costs will be proportional to the cost of hydrogen in $\$ / \mathrm{kg}$ and inversely proportional to the fuel economy in miles $/ \mathrm{kg}$.

We have previously assessed the expected fuel economy improvement of a FCEV over a gasoline car based on data in the literature ${ }^{13}$. This survey showed an average estimate of 2.4 times higher fuel economy compared to a conventional gasoline vehicle of the same size. More recently, engineers from DOE's National Renewable Energy

${ }^{12}$ One $\mathrm{kg}$ of hydrogen has 0.1136 MBTU of energy on a lower heating value basis, and gasoline typically has 0.115 MBTUs of LHV energy, although the value varies depending on the exact contents of gasoline. So $\$ 2.87 / \mathrm{kg}$ is equal to approximately $\$ 2.91 /$ gallon of gasoline on an energy-equivalent basis.

${ }^{13}$ C.E. Thomas, "Transportation options in a carbon-constrained world: hybrids, plug-in hybrids, biofuels, fuel cell electric vehicles and battery electric vehicles," Int. J. of Hydrogen Energy 34 (2009) 9279-9296. 
and the Savannah River National Laboratory outfitted two Toyota Highlander SUV FCEVs (which Toyota labels the "FCHV-adv") with instrumentation and measured an average fuel economy of 68.3 miles per $\mathrm{kg}$ of hydrogen over California roads that approximated average city and highway driving ${ }^{14}$. This is equivalent to $69.1 \mathrm{mpg}$ of gasoline on an energy equivalent basis. The conventional gasoline Toyota (non-hybrid) Highlander SUV achieves 20 to $22 \mathrm{mpg}$ fuel economy. So this first direct comparison of on-road fuel economy yielded three times higher fuel economy for the fuel cell version of the Highlander compared to the gasoline version. Thus the 2.4 times higher fuel economy used in the following charts may be conservative. The engineers also certified an average range of 431 miles for these SUV FCEVs with $70 \mathrm{MPa}$ hydrogen storage tanks.

The cost per mile for gasoline and for hydrogen will depend on the cost of petroleum and natural gas respectively. Figure 11 summarizes the EIA estimated fuel costs of gasoline in $\$ /$ gallon and natural gas in \$/MBTU-HHV through 2030 from their 2009 Annual Energy Outlook in constant 2007 dollars ${ }^{15}$. Without highway taxes, the average gasoline price is projected to stabilize around \$3.50/gallon, while the price for industrial natural gas would rise from $\$ 7 / \mathrm{MBTU}$ to $\$ 9 / \mathrm{MBTU}$. To better compare the cost per unit energy, we converted the gasoline \$/gallon prices to \$/MBTU in Figure 12, showing that the EIA expects the price of untaxed gasoline to increase significantly compared to natural gas over the next 20 years. On an equal energy basis, gasoline is predicted to rise from 2.4 times the cost of natural gas per MBTU up to 3.6 times more costly. Therefore converting natural gas to hydrogen has the potential to be less costly per unit energy than gasoline.

We have plotted the expected cost per mile for a conventional gasoline (non-

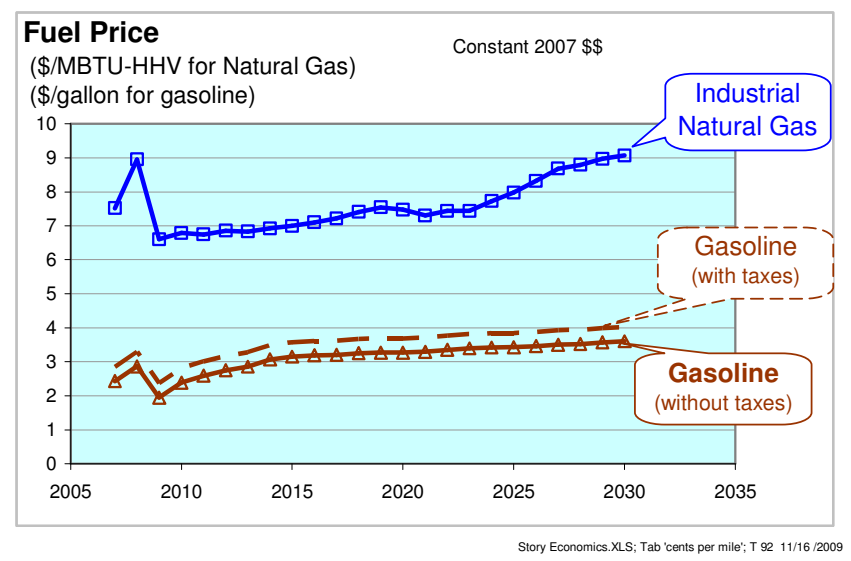

Figure 11. EIA projections of natural gas costs (in $\$ / M B T U-H H V)$ and gasoline (in \$/gallon) through 2030

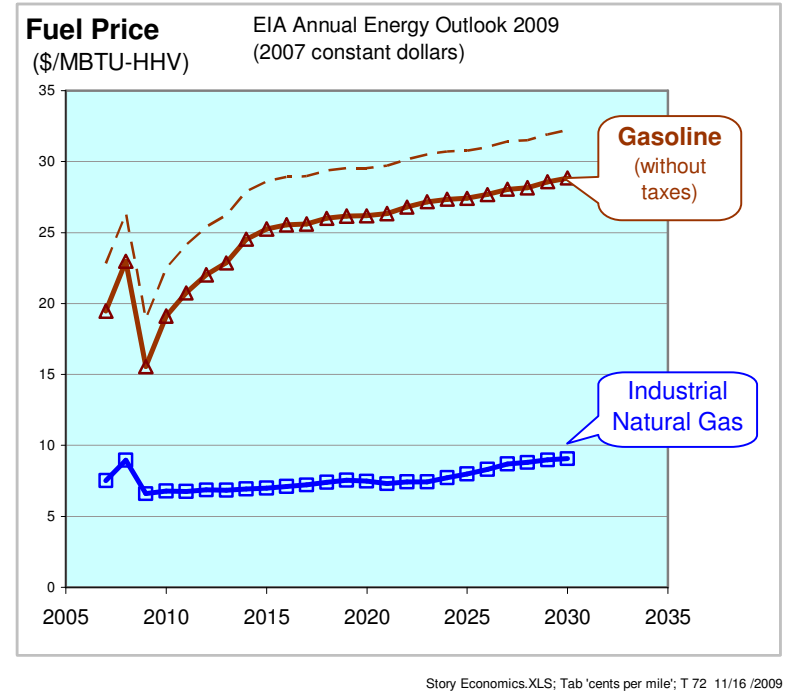

Figure 12. EIA projections of natural gas and gasoline prices, both in \$/MBTU-HHV

\footnotetext{
${ }^{14}$ K. Wipke, D. Anton, \& S. Sprik, "Evaluation of range estimates for Toyota FCHV-adv under open road driving conditions," NREL and SRNL Report \# SRNS-STI-2009-00446. http://www.nrel.gov/hydrogen/pdfs/toyota fchv-adv range verification.pdf

${ }^{15}$ http://www.eia.doe.gov/oiaf/aeo/index.html
} 
hybrid) car, a hybrid electric vehicle (HEV) and a FCEV between now and 2030 using the EIA projections for the costs in Figure 13. For the FCEV, we plotted six curves, assuming deployment of the existing HGM-10,000 (578 kg/day) fueling system developed under this contract (including CSD) with production quantities of one, 100, and 500 units, and a second set of three curves assuming the proposed scaled-up $1,500 \mathrm{~kg} /$ day fueling system, again with one, 100 , and 500 production quantities. We also included the fuel cost per mile that would result if the DOE hydrogen production cost targets of $\$ 2.50 / \mathrm{kg}$ by 2010 and $\$ 2.00 / \mathrm{kg}$ by 2015 were met.

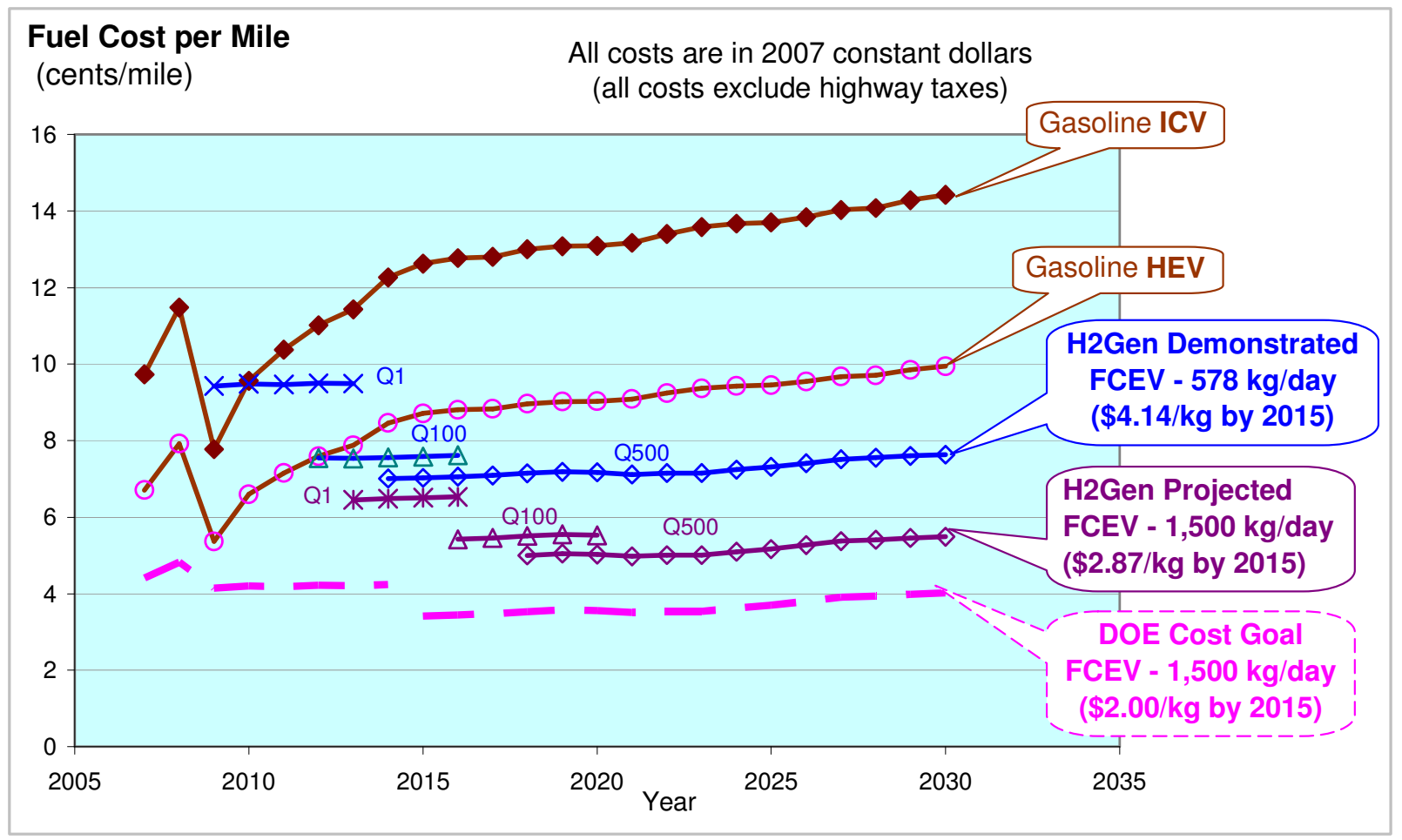

Story Economics.XLS; Tab 'cents per mile'; K 78 11/16/2009

Figure 13. Estimated vehicle fuel costs in cents/mile through 2030 for conventional gasoline internal combustion vehicles (ICVs), gasoline-powered hybrid electric vehicles (HEVs) and fuel cell electric vehicles (FCEVs); the ICV fuel economy is fixed at $25 \mathrm{mpg}$; the HEV fuel economy is 1.45 times greater $(36.2 \mathrm{mpg})$, and the FCEV fuel economy is 2.4 times greater (60 mpgge or 59.3 miles/kg of hydrogen).

The analysis summarized in Figure 12 leads to several very interesting conclusions:

- Hydrogen from the existing $578 \mathrm{~kg} /$ day SMR system is already cost competitive with untaxed gasoline per mile driven without any mass production cost reduction.

- Producing 100 of the $578 \mathrm{~kg} /$ day systems would make hydrogen in a FCEV competitive with untaxed gasoline in a hybrid electric vehicle.

- At 500 production levels, the current $578 \mathrm{~kg} /$ day system would produce hydrogen costs $20 \%$ less per mile than untaxed gasoline in an HEV. We conclude that scaling up to $1,500 \mathrm{~kg} /$ day is not necessary to make hydrogen competitive with gasoline. 
- Hydrogen from the first $1,500 \mathrm{~kg} /$ day fueling systems is projected to cost $25 \%$ less than untaxed gasoline in an HEV without any mass production cost reductions.

- At the 500 production level, hydrogen from the $1,500 \mathrm{~kg} / \mathrm{day}$ fueling system would cost $45 \%$ less per mile than untaxed gasoline in an HEV (and $62 \%$ less than gasoline in an ICV)

- While desirable, we do not need to meet the DOE cost targets of $\$ 2.50 / \mathrm{kg}$ by 2010 or $\$ 2.00 / \mathbf{k g}$ by 2015 . The $\$ 2.87 / \mathrm{kg}$ projected for the $1,500 \mathrm{~kg} /$ day system provides nearly a $50 \%$ cost reduction over untaxed gasoline in an HEV.

\subsection{Hydrogen from Ethanol}

While hydrogen made from natural gas used in a fuel cell electric vehicle reduces greenhouse gas emissions by more than 50\% compared to burning gasoline in a conventional car, cutting GHGs to $80 \%$ below 1990 levels as recommended by climate change experts will require moving to "greener" hydrogen. Hydrogen can be made with zero or near-zero GHGs by electrolyzing water using PV or wind energy, but these options are costly today. In addition, for the foreseeable future, GHGs can be reduced more by displacing (mostly coal-based) grid electricity with renewable electricity rather than by making hydrogen for FCEVs.

Another nearer term option to reduce the carbon footprint of hydrogen production is to reform ethanol at the fueling station. In effect, ethanol becomes the liquid carrier to transport hydrogen molecules from the farmer's field to the fueling station. The relative costs of fuel per mile traveled are compared in Figure 14. This figure illustrates that hydrogen made from ethanol selling at $\$ 1.50$ /gallon in a FCEV will cost more at 8 cents/mile than hydrogen made from natural gas at $5.2 \mathrm{cents} / \mathrm{mile}$. But the hydrogen from ethanol pathway is still less costly than gasoline in a hybrid $(9.5 \mathrm{cents} / \mathrm{mile})$, and is much less costly than hydrogen derived from either wind or PV with the assumptions used here. While the current corn-ethanol process utilizes considerable fossil fuels in the production of fertilizer, pesticides, herbicides, diesel fuel for farm machinery and natural gas or coal to run the ethanol plant, cellulosic ethanol should significantly cut down fossil fuel consumption with the lignin from the plant material providing the necessary fuel for the ethanol plant. 


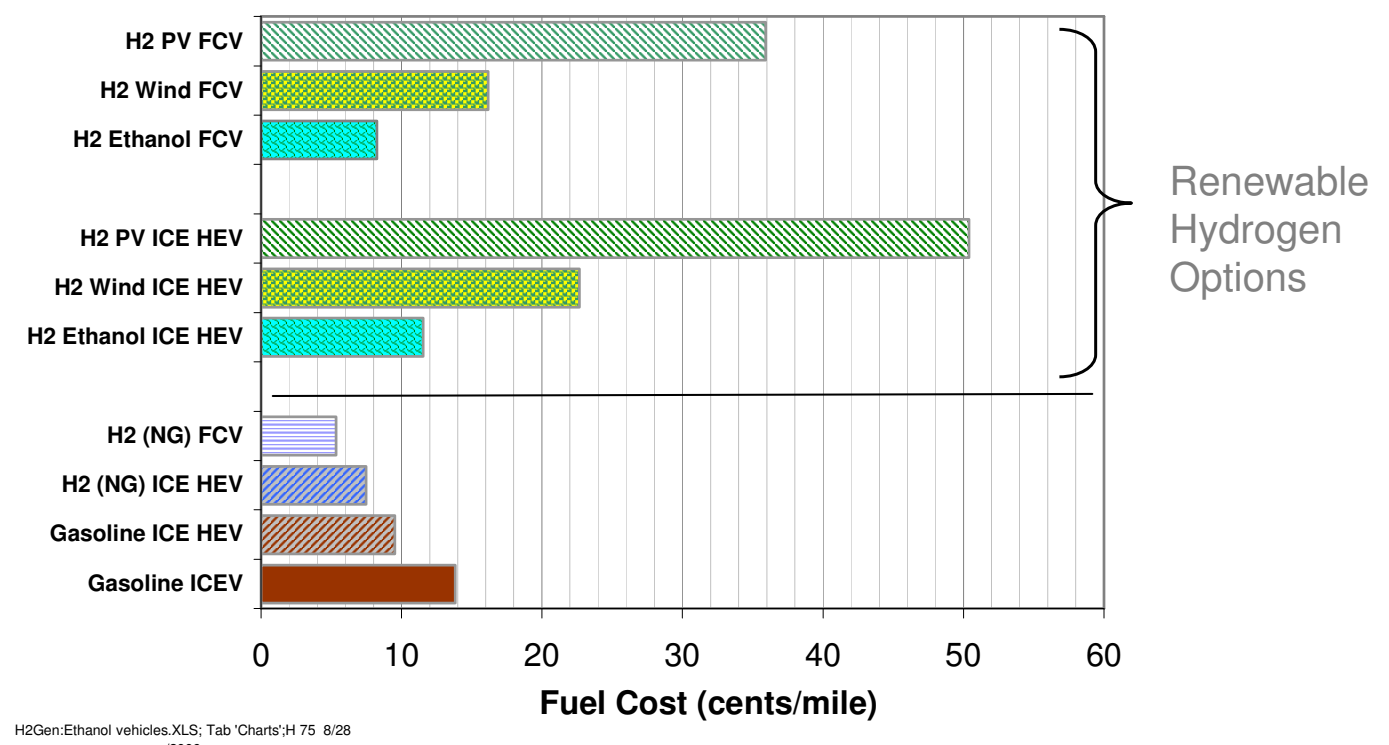

H2Gen:Ethanol vehicles.XLS; Tab 'Charts';H 75 8/28 /2006

\section{Figure 14. Estimated fuel cost per mile for various alternative vehicles}

Assumptions for Figure 14: Gasoline $=\$ 2.90 /$ gallon; Ethanol $=\$ 1.50 /$ gallon; PV $=20$ cents $/ \mathrm{kWh}$ for 7 hours $/$ day; Wind $=5$ cents/kWh for 12 hours/day; Gasoline-HEV fuel economy $=1.45 \mathrm{X}$ ICEV; H2-HEV fuel economy $=1.71 \mathrm{x}$ ICEV; FCV fuel economy $=2.38 \mathrm{X}$ ICEV [DOE cost parameters: $11 \%$ annual capital recovery, $90 \%$ capacity factor, $\mathrm{NG}=\$ 3.97 / \mathrm{MBTU}(\mathrm{HHV})$, Electricity= 7 cents $/ \mathrm{kWh}]$

$\mathrm{FCV}=$ fuel cell vehicle; $\mathrm{HEV}=$ hybrid electric vehicle; $\mathrm{ICE}=$ internal combustion engine; $\mathrm{NG}=$ natural gas

Some observers have questioned why we should convert ethanol to hydrogen instead of using that ethanol directly in a conventional car or hybrid. Figure 15 illustrates the answer. In this example, one gallon of ethanol could propel a conventional car about 16.5 miles, assuming the gasoline version of the car had a $25 \mathrm{mpg}$ fuel economy. That one gallon of ethanol could power a hybrid for 23.9 miles, but if we convert that gallon of ethanol to hydrogen with a $76 \%$ HHV efficiency (71\% LHV), it could power a FCEV for 28.3 miles. In other words, the improved fuel economy of the FCEV more than makes up for the energy loss in converting ethanol to hydrogen. In addition, only the FCEV would produce zero urban air pollution.

To evaluate the efficacy of reforming ethanol, the second project under this contract sought to demonstrate the feasibility of reforming ethanol at the fueling station as a lowcost renewable hydrogen option. We conducted a series of laboratory experiments, first on neat ethanol, and later using E-85 that contains 15\% gasoline denaturant from a local fueling station. 


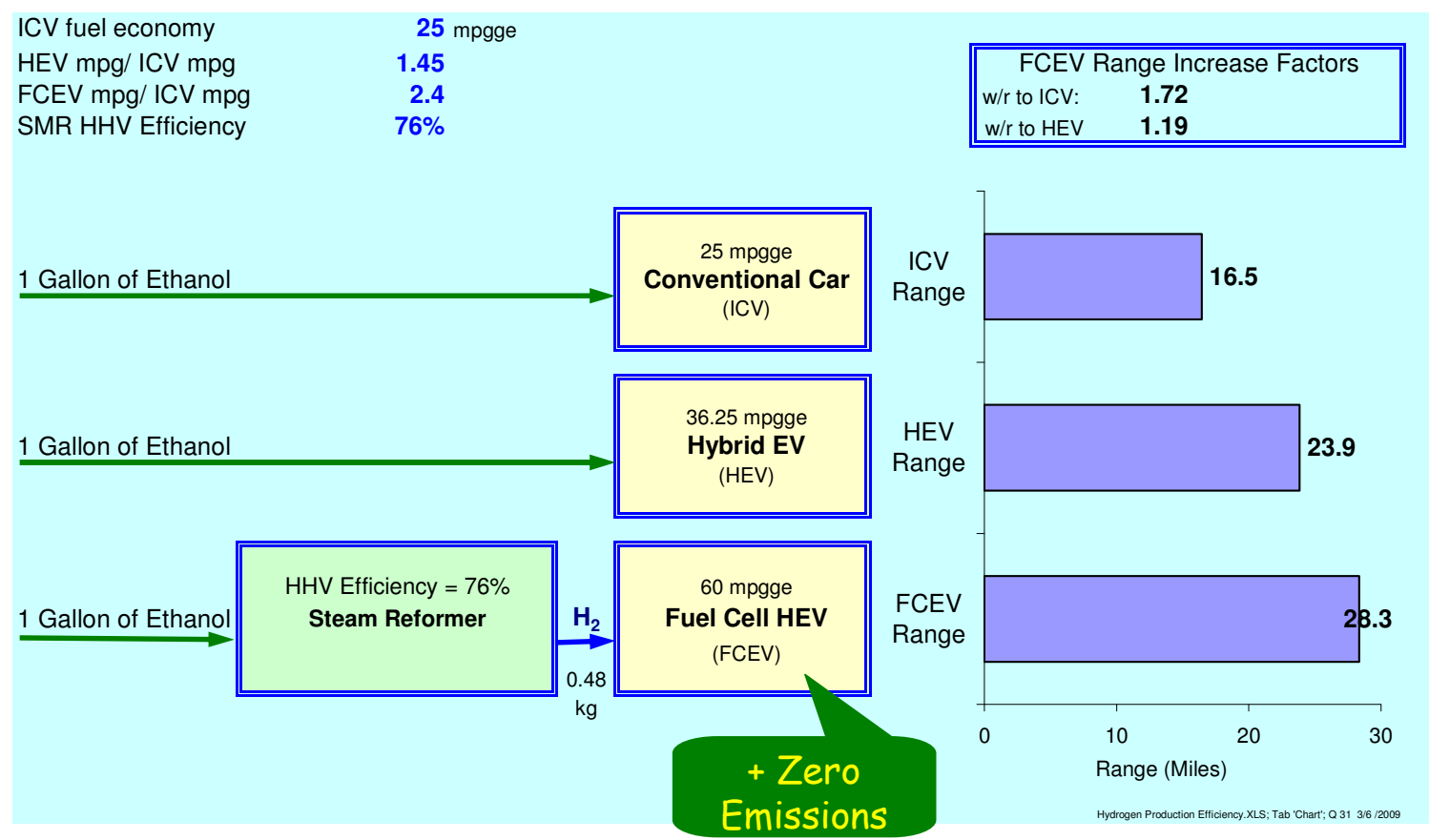

Figure 15. Comparison of miles traveled on one gallon of ethanol for a conventional internal combustion car, a hybrid electric car, and in a fuel cell electric vehicle

\subsection{Neat Ethanol Reforming Experiments}

Ethanol is currently made from fermentation of corn kernels, followed by distillation to remove most water for use as a fuel additive to gasoline. For use in a steam reformer, we would not need to remove all the water, which would cut down some of the ethanol plant costs. We therefore obtained samples of ethanol from a Midwestern ethanol plant from various stages in the distillation process. We were concerned that some of the ethanol from the earlier stages might include impurities that would degrade our reformer catalysts. The following tests were run with reflux ethanol containing $7.76 \%$ water.

The microreactors simulate the expected process in the full-size $\mathrm{H}_{2} \mathrm{Gen}$ reformer system. The microreactor tubes are 27 inches long with the following catalyst sections:

- 6" pre-reforming section

- 9" reformer section

- 6" ultra-high temperature WGS section

- 6" WGS section

The first test of ethanol reforming lasted just under 1,000 hours when a large pressure drop was observed. The tube was cut open and coke was seen throughout the prereformer and reformer sections. Subsequent analysis showed that this coking was most likely caused by iron oxide that had accumulated in the bottom of a mild steel ethanol tank. 
A second long-term aging test with reflux ethanol lasted 1,900 hours before the pressure drop across the tube increased from the nominal 180 psi to 200 psi. Again the tube was cut open. Coke was observed in the upper 2" of the pre-reformer catalyst in this test. The rest of the pre-reformer section and the other three sections were clean and coke-free. We suspect that this sudden coking was caused by either a low water condition or a low temperature condition in the microreactor during weekend operation. The pre-reformer catalyst performed well throughout the 1,900 test as shown by the composition (nominally 60\% hydrogen, $20 \%$ methane, 12\% carbon dioxide and $8 \%$ carbon monoxide) exiting this section as shown in Figure 16.

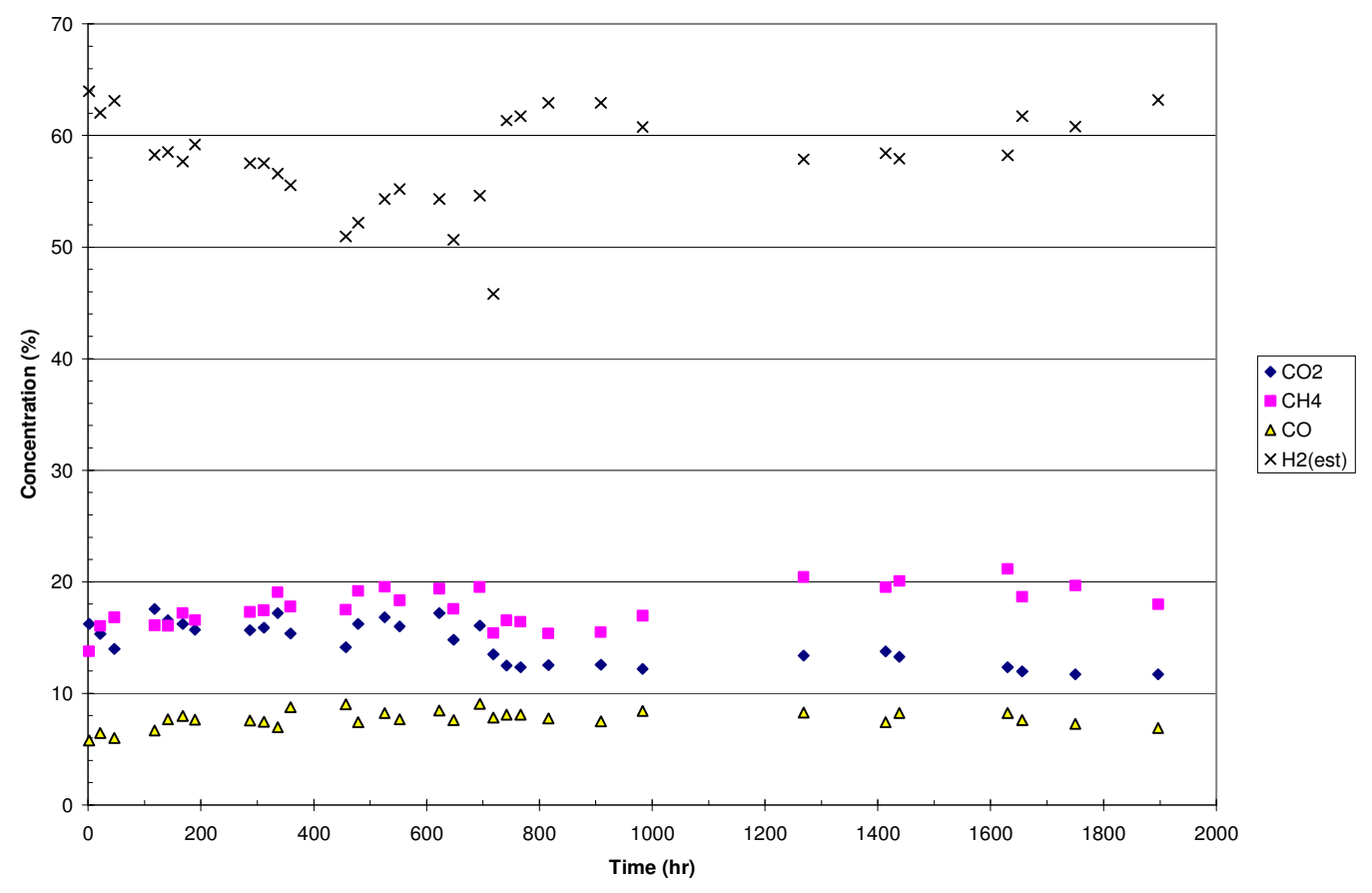

Figure 16. Composition of gases exiting the pre-reformer section with reflux ethanol input

Other tests were also run on the corrosion inhibitors added to fuel ethanol. These inhibitors (Tolad 3224, Nalco 5403 and DLi-11) did not adversely affect ethanol reforming during short term screening tests.

\subsection{E-85 Reforming Experiments}

Fuel grade ethanol is typically denatured with $5 \%$ gasoline or natural gas liquids at the ethanol plant for bulk shipment to regional distribution centers. The gasoline denaturant prevents this ethanol from being sold or used for internal consumption and also assures good cold-start capability. The mixture is further diluted to $85 \%$ ethanol and nominally $15 \%$ gasoline at the distribution centers for shipment to local fueling stations, the socalled E-85 fuel used in some parts of the country. We obtained E-85 for our next set of experiments from a fueling station in Arlington, Virginia to see if our reformer process 
could tolerate the $15 \%$ gasoline. We also planned to test E-95 as a fall-back position if the $15 \%$ gasoline was too degrading, ${ }^{16}$ but we did not have the time to run E-95 tests.

The initial E-85 reformer test proceeded successfully for 300 hours, but was stopped when a significant pressure drop was observed. After cutting open the reactor tube, we found plugging and coke in the reformer section, but not in the pre-reformer catalysts or in either WGS zone. Analysis detected traces of silicon and phosphorous in both the pre-reformer and in the reformer section where coking occurred. The pre-reformer catalyst has a different substrate than the reformer catalyst, which may account for the poisoning on the latter but not the former.

We therefore started another long-term aging test using all pre-reformer catalyst. This test ran successfully with E-85 for 2,700 hours as shown by the output from the microreactor in Figure 17, showing and average hydrogen content of $75 \%$.

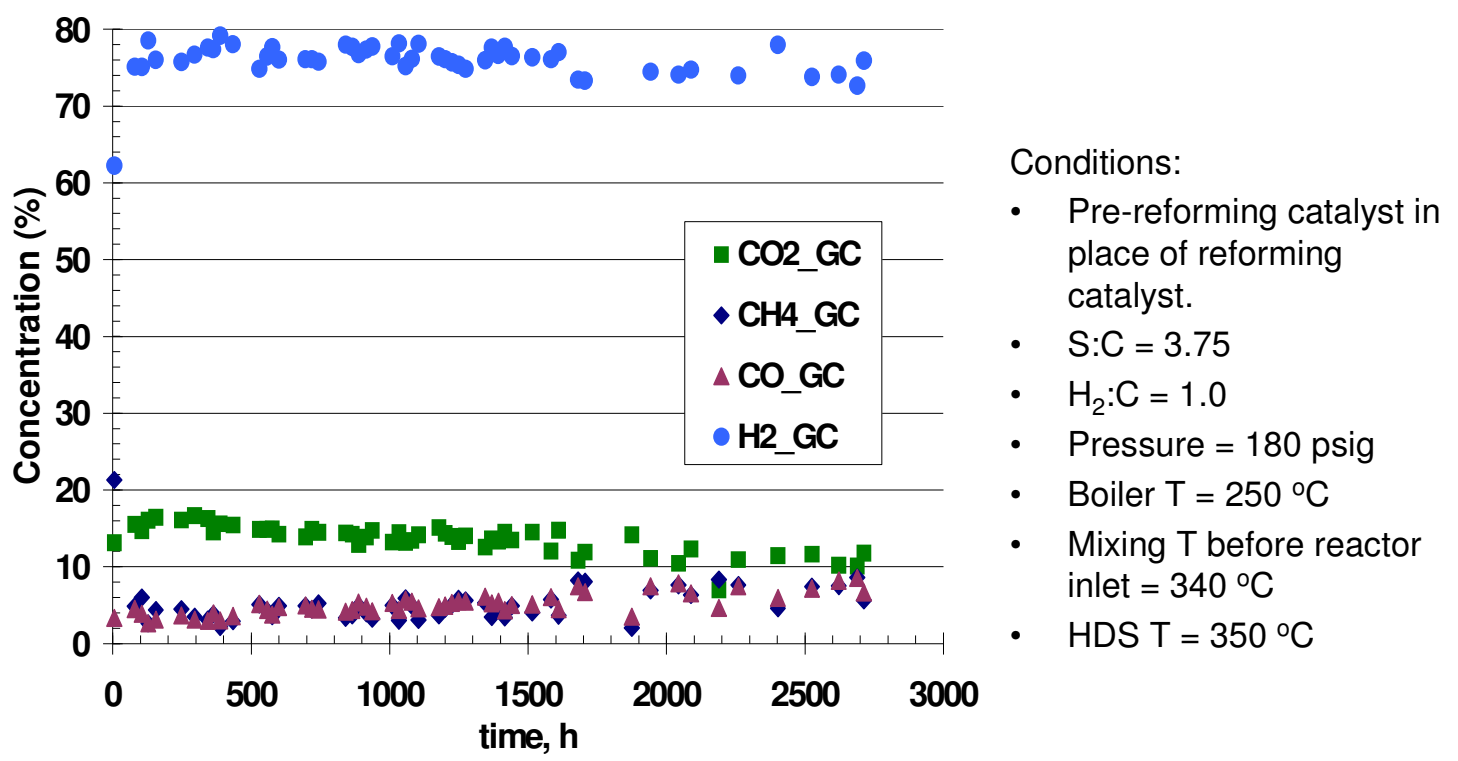

Full conversion of ethanol to syngas.

Stable product composition.

Figure 17. Output gas composition from the E-85 microreactor long-term aging test

\subsection{Catalyst Coated Wall Tests}

We originally planned to design an HGM-3,000 reformer to run on ethanol, with the expectation that the DOE might fund an extension of this contract to further develop the ethanol reformer system. One of the initial design tasks was to build and test a prototype ethanol burner for the reformer system. This was the only major new

\footnotetext{
${ }^{16}$ Another further fall-back position would be to use methanol as a denaturant, which would most likely be easily reformed. But since E-85 is already used as a motor fuel in some parts of the nation, it would be the most readily implemented source of ethanol at fueling stations.
} 
component of the system, since the pre-reformer produces a hydrogen/methane mix that can use our current SMR system. However, we were not able to find any burner manufacturer that would certify their burner operating with alcohol fuel. They were concerned that the low flash temperature of liquid fuels would constitute a serious detonation risk. One option would be to use natural gas or propane to fire the burner originally, and they switch to the PSA tailgas plus trimgas to keep the burning running. The remaining funds would not be adequate to develop a new burner system, so we proposed and the DOE manager accepted an alternative task to improve the chances of a successful ethanol reformer system: a catalyst-coated reactor tube.

Coating the catalyst on the inside wall of the reformer tube could have several advantages over the current catalyst packed-bed reformer:

1. Reduced the risk of coking. In most cases coking originates from fuel cracking on the hot, inert wall of the reformer tube. Coke then propagates to encapsulate the catalyst gradually restricting the gas flow and the heat flux through the tube. This mechanism was supported by the results of the 2,700 hour aging test of E-85 fuel when a dense layer of fibrous coke was found on the inner wall of the reforming tube. Coating the catalyst directly onto the wall of the reformer tube will reduce this risk by eliminating the hot, inert surface. In the coated tube reformer, the catalyst will be the hottest surface contacted by the reacting stream, decreasing the likelihood of fuel decomposition and increasing selectivity towards the reforming reaction. Coke formation on the section of the coated wall would result in formation of a hotter catalyst around this spot, likely leading to carbon gasification into $\mathrm{CO}$ or $\mathrm{CO}_{2}$ by excess steam and, thus, reversing of the onset of coking. Higher average temperature of the catalyst coated on the tube wall relative to the packed bed catalyst will also increase tolerance to poisoning.

2. Decrease of required tube size. Direct contact between the reactor tube wall and catalyst gives much better heat transfer rate than a traditional packed bed reactor. This in turn will result in a higher overall reaction rate and a smaller reformer for the same gas throughput, thereby reducing system cost by reducing the amount of expensive alloy tube required.

3. Minimize the pressure drop at high throughput. Placing the catalyst directly on the tube wall eliminates the flow resistance from the packed catalyst bed which leads to negligible pressure drop and the possibility of running at much higher throughputs.

4. Reduced wall temperature. The tube wall must necessarily be hotter with a packed bed to drive the convective and radiative heat transfer to the catalyst pellets. Cooler walls might allow the use of less expensive tubes and/or provide longer tube life.

5 Potential for one-step stream reforming of biomass into syngas. The open tube design of the coated catalyst SMR and high throughput rates achievable for this process can allow the residue from biomass gasification process to pass through the tube without plugging it. This may result in a one-step steam reforming of biomass that can be followed by a synthesis reaction producing liquid fuels (Fischer-Tropsch diesel, 
methanol or DME synthesis). Note that steam reforming produces syngas having higher $\mathrm{H}_{2} /\left(\mathrm{CO}+\mathrm{CO}_{2}\right)$ ratio than autothermal reforming and, therefore, is better suited for the downstream synthesis. Furthermore, steam reforming, being an endothermic reaction allows for utilization of waste heat streams and promises higher thermal efficiency than the ATR based systems.

Süd Chemie produced several sets of coated wall tubes for our experiments. Temperature programmed oxidation (TPO) was used to compare the degree of coking for both packed bed and coated wall tubes, using natural gas and E-85. Negligible coking was found even at low $\mathrm{S} / \mathrm{C}$ ratios with natural gas. Coking was observed with $\mathrm{E}-$ 85 , but the total measure coke formation was approximately three times less on the coated wall than with the packed bed under similar conditions. The coated wall tube temperature was only $650^{\circ} \mathrm{C}$ compared to $800^{\circ} \mathrm{C}$ for the packed bed under similar conversion rates.

The first test of the coated tube using natural gas had to be stopped when an overnight power failure shut down the furnace while water continued to flow from the DI bed, accidentally spraying water on the hot catalyst surface which delaminated the catalyst coating.

Subsequently, two separate tests of coated tubes were run for over 350 hours each: one with natural gas, and one with E-85. No significant pressure drop was detected in either experiment. The natural gas experiment showed that despite twice the flow rate through the coated wall tube compared to the packed bed HGM tube, there was no measurable pressure drop, compared to 1 bar pressure drop in the standard HGM tube.

In summary, our limited experiments with catalyst-coated wall tubes have demonstrated $150^{\circ} \mathrm{C}$ lower wall temperatures, negligible pressure drop compared to the packed bed reactor and acceptable reforming performance for both natural gas and E-85. Time did not permit any long-term aging experiments.

\subsection{Conclusions}

\subsection{Hydrogen Generation Conclusions}

> A $578 \mathrm{~kg} /$ day steam methane reformer and integrated pressure swing adsorption system was successfully designed, built and field-tested, and has now become a commercial product

$>$ This $578 \mathrm{~kg} /$ day SMR/PSA system, in conjunction with a compression, storage and dispensing (CSD) system, could supply compressed hydrogen to a fuel cell electric vehicle (FCEV) that would be cost competitive on a per mile basis with untaxed gasoline in a conventional (non-hybrid) car

$>$ Hydrogen from this $578 \mathrm{~kg} /$ day system, if produced in quantities of 100 units, would cost $20 \%$ less per mile than untaxed gasoline in a hybrid electric vehicle (HEV) 
$>$ Hydrogen from a scaled up $1,500 \mathrm{~kg} /$ day SMR/PSA system is projected to cost $25 \%$ less per mile than untaxed gasoline in an HEV without any mass production cost reductions

> Produced in quantities of 500 units, this $1,500 \mathrm{~kg} /$ day fueling system could produce hydrogen at $\$ 2.87 / \mathrm{kg}$, which would cost $45 \%$ less per mile than untaxed gasoline in an HEV, and $62 \%$ less per mile than untaxed gasoline in a conventional (non-hybrid) vehicle.

$>$ We conclude that achieving the DOE hydrogen cost targets of $\$ 2.50 / \mathrm{kg}$ to $\$ 2.00 / \mathrm{kg}$ is not necessary for hydrogen to be cost competitive with untaxed gasoline in the 2015 to 2030 time period, based on current EIA projections of gasoline and natural gas prices

\subsection{Ethanol Reforming Conclusions}

$>$ Reforming ethanol at the fueling station is the least costly renewable hydrogen option at this time

$>$ We have shown by laboratory micro-reactor experiments that reflux ethanol with $7 \%$ water can be effectively reformed using catalysts developed by Süd Chemie

$>$ Reforming E-85 with 15\% gasoline denaturant is more challenging, although we were able to run one reformer test for 2,700 hours before a power failure interruption led to coking.

$>$ Initial experiments with a coated wall reactor tube showed promise, with less propensity to coke, $150^{\circ} \mathrm{C}$ lower wall temperature, and no detectable pressure drop compared to one bar pressure drop with the standard packed bed reactor.

$>$ Further resources will be required to develop a fully functional ethanol reformer system. 